Original Research Paper

\title{
Barriers to Children and Young People's Participation in Policy Making in Ghana
}

\author{
Jones Adu-Gyamfi \\ Social Work and Social Care, University of Bradford, United Kingdom
}

Article history

Received: 09-10-2014

Revised: 04-04-2015

Accepted: 10-09-2015

\begin{abstract}
This research examined the barriers to young people's participation as strategic stakeholders in the formulation of public policy, using the formulation of Ghana's youth policy as a case study. The aim was to gain knowledge about the processes that facilitate or hinder young people's participation in the policy process at national level. The study involved the use of semi-structured interviews and focus group discussions with 20 stakeholders in the policy process. Findings showed discrepancy in the attitudes and behaviour of policy makers towards young people. For example, on one hand policy-makers recognised young people's right to participate but on the other hand they did not seek to involve young people in the policy process. This paper presents a number of factors contributing to this discrepancy and how to overcome them. The paper concludes that to effectively involve young people in the formulation of public policies young people must possess and exercise democratic franchise.
\end{abstract}

Keywords: Youth Participation, Ghana, Policy Formulation, Barriers to Participation

\section{Introduction}

Citizenry participation in the process of formulating and implementing public policies is considered to be a major pillar of good governance (McFerson, 2009 cited in Kpessa, 2011). There is therefore a continued emphasis on the need to promote public participation in the policy process (Gyimah-Boadi, 2004; Harrold, 2000). Research into citizenry participation in the policy process has however focussed on adults and civil society organisations (Kpessa, 2011). This study focused on children and young people's participation in the policy process. It is hoped that the study would shed more light on children and young people's participation in policymaking. The paper used the formulation of Ghana's national youth policy as a case study to outline the barriers to involving young people in public policymaking. The first section of the paper is devoted to outlining the barriers to young people's participation, while the second section looks at overcoming the barriers. The findings of the study strongly suggest that 15-17 year olds have more commonalities with adults, in terms of their desire to be included in governance systems. The study urges policy-makers and politicians to re-think teenagers and politics and realise that young people are not disinterested in policy-making.

\section{Problem Statement}

Although there are increasing efforts to involve youth (broadly defined) in development processes, those at the lower end of youth definition (i.e., 15-17 year olds) are still often excluded. This has resulted in a 'research deficit' on 15-17 year olds; for they are not generally considered children so they are excluded from childhood research (usually between 5-14 years) and they are also not considered adults hence excluded from adulthood research (usually $18+$ years). The overwhelming majority of literature on children's participation reflect research either in family decision-making including divorce cases, children in State's care-child protection or looked after children's care planning and reviews (e.g., Kassan, 2004; Fitzgerald, 2009; Eriksson and Näsman, 2008; Thomas and O'Kane, 1999; Gunn, 2005 ; 2008) or on children's involvement in school decision-making (e.g., Cox et al., 2010; Ochaíta and Espinosa, 1997; Veitch, 2009). A few researchers have looked at children's participation in health (e.g., Vis et al., 2010), environment (Horelli, 1998) and in public sphere at the municipal/local level (e.g., Williams, 2004; Fanelli et al., 2007).

Evidence of children's participation at national and/or international level is very limited. Perhaps this is 
not surprising, given that the most difficult area to assess the impact of children's participation is public policy (Williams, 2005; Shier, 2001). Kirby and Bryson (2002) have noted that in spite of the growing attempt to involve young people in public decision-making, research and evaluation of such efforts is lacking. Pinkerton (2004) adds that evaluation of young people's participation in public decision-making is not easily undertaken. Consequently, children's involvement in the policy process has been given limited attention. It has however been demonstrated that children and young people do have the capability to participate in national policy processes. In a study in Zimbabwe, Fanelli et al. (2007) interviewed 2 child representatives out of 3 and also held focus group discussions with 30 adult community volunteers to gather their views and experiences on Zimbabwe's national action plan for orphans and other vulnerable children. They reported that young people actively shared in the agenda setting and formulation of the plan. However, at the implementation stage, the young people were relegated to community level implementation committees; there were no child representative at the national implementation committee.

Pinkerton (2004) also reports of children and young people's involvement in the development of the Irish National Children's Strategy in which over 1000 children and young people were consulted over a 12 month period. There were two committees championing the development of the strategy; (1) inter-developmental group made up of 8 members tasked with developing the strategy and supported by (2) cross departmental team also consisting of 8 members. However, none of these committees where decisions were made had children and young people's representation. A similar result was found by Williams' (2004) study on five South Asian projects in 4 countries ( 2 projects in India and 1 each in Nepal, Sri Lanka and Bangladesh) on how children and young people influence policy. She undertook a deskstudy of the projects and supplemented it with telephone interviews and email questionnaire administration with relevant NGO staff and government actors. The study revealed that young people's influence was more evident at local levels than national levels and at the agenda-setting stage and no other decision-making stages. Williams' study is among the few studies that have examined children and young people's influence at the policy level, but the lack of fieldwork meant that there were no young people's inputs into the research, which she duly acknowledged.

It is thus evident that research on children and young people's participation in public policy making is limited. Studies that have looked at children and young people's participation in policy making have examined local and/or organisational policy making in respect of service development or looked after care planning (e.g., Gunn, 2002; 2005; 2008; Checkoway et al., 2005). Very few studies have examined children's participation in national policy making (e.g., Pinkerton, 2004; Spicer and Evans, 2005).

\section{Literature Review: Approaches to Policy Formulation}

\section{Linear Approach}

This is also referred to at the rational model. In this model policy making is assumed to involve 'a series of sequential phases, starting with the identification of a problem or issue and ending with a set of activities to solve or deal with it' (Sutton, 1999: 9). Thus the policy process flows sequentially from agenda phase through decision phase and ending at the implementation phase. Grindle and Thomas (1991) argue that policy development does not begin until policy makers are convinced that the issue is important enough for them to spend time considering. In other words the issue in the first instance must make it onto the agenda. In this regard, Gerston (1997) outlines three criteria that an issue must satisfy to be on the agenda: It must have sufficient scope (a significant number of people or communities are affected); intensity (the magnitude of the impact is high) and/or time (it has been an issue over a long period). However it can be argued that an issue need not to have existed for a long period of time before it can be placed on the agenda. In this regard what Birkland (2005: 101) terms focusing events i.e., "sudden events that are ... actually or potentially harmful" is a useful example.

The linear approach emphasises the rationality of policy makers and their ability to make the best decisions on policy choices. It suggests that policy formulation is a rational process that involves several well defined steps i.e., the decision-maker acquires all necessary information, compares different options and then selects the option that gives maximum gains (Parsons, 1995). It assumes that policy making starts with problem identification, followed by setting and ranking of goals and objectives. Then the various alternatives for dealing with the problem are examined including cost-benefit analysis. Finally, on the basis of this examination the alternative that maximises the attainment of the goals and is value for money is chosen (Anderson, 1975).

This approach further assumes that state officials are neutral and so their own interests do not influence public policies. However, this is criticised as unrealistic and that there are evidence that suggest that policy makers usually have some interests that they seek to satisfy (Teye, 2008). According to Teye 
'state managers collectively are self-interested managers, interested in maximising their power, prestige and their wealth' (Teye, 2008:42). Similarly, Levi argues that:

Government officials respond to incentives and disincentives. They are unlikely to undertake policies that are generally unpopular or that will lose them powerful support. They make deals that keep them in power and maintain revenue, votes, or whatever underlies their power (Levi, 1988 cited in Mooij, 2003:7).

\section{Bounded Rationality/Incrementalism}

In acknowledgement of the argument that policy makers seek to be rational but do not succeed because of bounds or limits to their capacities, the bounded rationality and incremental models were propounded (Simon, 1957; Lindblom, 1959 respectively). Simon (1957) argues that policy makers could and should become more rational in decision making since they often want to be so. According to him 'human behaviour in organisations is, if not wholly rational, at least in good part intendedly so' (Simon, 1957: xxiii). Bounded rationality suggests that policy makers behave as rationally as possible within certain limits, including limited information, limited time and limited human ability to see every pattern of a problem. He suggested that policy makers could improve their rationality by relying on specialist groups for decision making.

Lindblom (1959) rejects the argument that policy makers could and should be more rational. He argues that comprehensive rationality in policy making is not possible, therefore policy formulation proceeds incrementally. He argues further that policy makers 'rely heavily on the record of past experience with small policy steps to predict the consequences of similar steps extended into the future' (Lindblom, 1959: 79). In other words, policy makers make decisions in relatively small increments, rather than in big leaps. They do so by comparing the successes and failures of previous or existing policies that have been taken to address a problem. Incrementalism as a concept implies 'change by small steps' (Lindblom, 1979: 517). Thus policy makers consider only some of the alternatives for dealing with a problem, which may differ only marginally from existing policies instead of starting afresh. Lindblom (1959) further argues that 'policy is not made once and for all; it is made and re-made endlessly' (p. 86) because policies achieve only part of what was hoped for and also produce unanticipated consequences. Hence by proceeding with incremental changes policy makers can avoid serious lasting mistakes in several ways. Lindblom called his approach 'successive limited comparisons'
(1959: 81), however in the literature his approach is commonly referred to as incrementalism.

The incremental model can be criticised for its inability to account for abrupt changes in policy or situations where policies are outrightly abrogated, since it is only concerned with marginal changes in existing policy. Dror (1964) also argues that in the absence of any past policies in respect of an issue, incremental change is in fact impossible. He notes that technological and behavioural changes bring about new actions, which, unless ignored, lead to radically new policies. For example, advances in medicine such as In Vitro Fertilisation (IVF) and surrogacy has led to laws on embryology in many countries; the internet and advent of social media is pushing the boundaries between privacy and freedom of speech. These demand new policies which incrementalism cannot address.

Moreover, incrementalism is criticised for its inability to deal with problems that demand bold decisions that cannot be simply met with incremental steps, e.g., decision to go to war (Birkland, 2005). In addition, Boulding (1964 cited in Etzioni, 1967) criticises the incremental approach as steps that may be circular and lead back to where it started, or dispersed steps that lead to many directions at once but leading to nowhere in particular i.e., 'action without direction' (Etzioni, 1967: 388). Finally, it is argued that practising incrementalism can stifle societal innovations since it implies seeking no more than limited variations from past policies (Etzioni, 1967). Consequently True et al. (1999: 103) critique it as 'at best, an incomplete explanation of government policy making and, at worst, a misleading one'.

To Lindblom's credit, he acknowledged that his approach is 'remedial, geared more towards the alleviation of present, concrete imperfections than to the promotion of future social goals' (Lindblom, 1965 in Etzioni, 1967: 387). Nonetheless he asserts that drastic policy change or carefully planned big steps is not ordinarily possible (Lindblom, 1979). He thus reinforces Smith's (1973) claim that incremental policies are much easier to implement than ambitious non-incremental ones. He responded to criticisms that incrementalism is not suited for dealing with complex problems by arguing that 'complex problem solving means practising incrementalism more skilfully' (Lindblom, 1979: 517). He however failed to provide any methodology or strategy for such skilful practice. Nonetheless incrementalism is highly regarded in the study of public policy. According to Dror (1964: 155) although there are many reservations about Lindblom's thesis, 'these are insufficient to alter its main impact as an ideological reinforcement'. Parsons (1995) has also described Lindblom's work as a 'perhaps the single most important 
contribution to the formation of a theory of the policy making process' (p. 22).

\section{Mixed Scanning Model}

The Mixed Scanning model was propounded by Etzioni (1967) combining features of bounded rationality and incrementalism. He criticised the rational approaches as 'utopian', 'unrealistic and undesirable' and the incremental model as 'conservative' (Etzioni, 1967: $385,386)$. Etzioni argued that since it is not possible for policy makers to get all relevant information needed for a rational decision, they scan through the problem and make detailed examination of important areas and apply incremental procedures to other less important areas that do not need rapid changes. Mixed-scanning is defined as 'a hierarchical mode of decision-making that combines higher order, fundamental decision-making with lower order, incremental decisions that work out and/or prepare for the higher order ones' (Etzioni, 1986: 8).

In the exploration of mixed-scanning, Etzioni (1967) distinguishes between fundamental and incremental decisions. According to him, fundamental decisions set the context for incremental ones and are 'made by exploring the main alternatives the actor sees in view of his conception of his goals...but details and specifications are omitted so that an overview is feasible' (Etzioni, 1967: 389-390). It is very difficult to comprehend the distinction between fundamental and incremental decisions. Although Etzioni reiterates that incremental decisions are set on fundamental ones, he also states that 'fundamental decisions are frequently "prepared" by incremental ones in order that the final decision will initiate a less abrupt change' (Etzioni, 1967: 387). He leaves readers confused about whether the final decision is fundamental or incremental. In a later article, he attempted to answer how a fundamental decision could be distinguished from an incremental decision (Etzioni, 1986). He outlined that one way of differentiation is to look at relative size. As a rule of thumb he used $10 \%$ or less change i.e., if a decision results in less than $10 \%$ changes to budget, then it could be described as incremental, whereas a more than $10 \%$ change would be a fundamental decision. It is worth noting that this $10 \%$ rule is difficult to substantiate as many policy decisions do not result in changes to budgets. Another way to differentiate between fundamental and incremental decisions outlined by Etzioni (1986) is 'checking for a nestling relationship' (p. 10). He argued that 'if an incremental decision requires or draws on a contextual decision, this is the fundamental one' (p. 10). He did not however elaborate on what 'nestling relationship' means or what a 'contextual decision' is. He thus seems to introduce more concepts to confuse rather than clarify.

\section{Ideas Based Approach}

According to John (1998) it is impossible to imagine politics without ideas. The ideas based approach argues that policies are significantly shaped by ideas that can provide solutions to public problems (John, 1998) and that the adoption of a particular policy is determined by the quality of arguments that lobbyists present to policy makers (Sabatier and Jenkins-Smith, 1993). Consequently, the role of ideas brokers is crucial. As Haas (1992 cited in Parsons, 1995) rightly observed without people to carry ideas into the policy process an idea is unlikely to be influential. The acknowledgement that ideas are increasingly regarded as important in the policy process and the need to have ideas brokers heralded the growth of think-tanks in the 1970s and 1980s (Parsons, 1995).

Clarifying what is an idea is complex and often confusing. However, John (1998) offers some respite. According to him ideas can be 'statements of value or worth; they can specify causal relationship; they can be solutions to public problems; they can be symbols and images which express private and public identities; and ideas can be world systems and ideologies' (John, 1998: 144). Notwithstanding the difficulties in the precise definition of an idea, its advocates contend that it is important in public policy because it is the ideas that actors bring to the debate that influence policy change. For example, Haas (1992) argues that the diffusion of new ideas can lead to new patterns of behaviour that can prove to be an important determinant in policy coordination. Contrarily, Hall (1989 cited in Parsons, 1995) while recognising the importance of ideas also argues that there are other important factors which can make or mar the progress of ideas. Hall outlines three factors that are required for new ideas to influence policy making: (1) The idea must have a good fit with prevailing circumstances, (2) it must be seen to be in the interest of dominant political interests; and (3) it must be judged feasible administratively.

Some scholars are however sceptical of the adequacy of the idea based approach. Teye (2008) argues that the assumption that policy makers usually take ideas from individuals is overly optimistic. Echoing Hall's second factor, above, Teye (2008) reiterates that policy makers sometimes only accept ideas that are in consonance with their own interests. Other scholars also argue that changes in government and international policy may stimulate policy changes rather than ideas per se (e.g., Howlett and Ramesh, 2002).

\section{Policy Network Approach}

Rhodes (1997; Rhodes and Marsh, 1992; Marsh and Rhodes, 1992) is credited as a pioneer of the policy network approach (John, 1998). The approach posits that 
decision-making involves many different bodies that depend on each other and thus form a close dependant relationship within a policy domain. Out of this dependence policy networks emerge. In other words policy networks exist when there is an exchange of resources between various state and societal actors or between parts of the government (Smith, 1993; Birkland, 2005). The network approach understands the policy process to involve a diversity of mutually interdependent actors. It suggests that the policy process is shaped by interdependent interests of both state and societal actors (Smith, 1993; Carlsson and Sandstrom, 2008). According to John (2001) the network approach is more realistic, because it captures the complexity of the policy process. Likewise, Teye (2008) argues that the realisation that state actors are not neutral makes the network approach appropriate for analysing policies in developing countries where the interests of state actors cannot be ignored.

The policy network approach rejects the claims that politicians and bureaucrats are the sole generators of policies. Wilson (1980 cited in Teye, 2008) has argued that government policies cannot be fully understood without analysing the impact of interest groups and that the mere presence of interest groups and the networks between state and societal actors shape policies (Smith, 1993; Carlsson and Sandstrom, 2008). Whilst accepting that interest groups are much more important in the policy process, Birkland (2005) however disputes that their mere existence necessarily guarantees them a voice in policy making. He argues that some groups are more powerful than others and the power of a group depends on the resources available to the group. Hence groups that are able to provide specialist knowledge and information that policy makers draw on to take decisions are more likely to have an advantage in ensuring that their definition of the problem and proposed solution is taken into account. Groups that are also able to make financial contributions to parties and candidates during elections are more likely to be taken serious. As rightly observed by Sabatier (1988:143 emphasis in original) 'while belief systems will determine the direction in which any political actor will seek to move governmental programs, its ability to do so will be critically dependent upon its resources. These include such things as money, expertise, number of supporters and legal authority'.

The policy network approach has been criticised for placing too much emphasis on cooperation whilst ignoring power differences and conflicts. According to Sabatier and Jenkins-Smith (1999) conflicts are inevitable as groups compete with each other for members and grant funds, or even for credit in policy successes. Moreover it is argued that this approach only focuses on relationships between top state officials and leaders of groups during elite circles policy making, while ignoring micro-level inter-personal and informal relationships (John, 2001).

\section{Advocacy Coalition Framework}

This framework was propounded by Sabatier (1988) and later developed with Jenkins-Smith (Sabatier and Jenkins-Smith, 1993; 1999). An advocacy coalition is a group of "people from a variety of positions (elected and agency officials, interest group leaders, researchers) who share a particular belief system - i.e. a set of values, causal assumptions and problem perceptions - and who show a non-trivial degree of coordinated activity over time' (Sabatier, 1988: 139; Sabatier and Jenkins-Smith, 1999: 138). These beliefs, which Sabatier and JenkinsSmith called policy core beliefs, include agreements over basic cause of the problem, its seriousness and the instruments to employ to solve the problem. According to them agreement over policy core beliefs is the principal glue that holds a coalition together and coalitions seek to translate those beliefs into public policy 'by influencing the behaviour of multiple governmental institutions over time' (Sabatier and Jenkins-Smith, 1993: 212). The framework holds that advocacy coalitions and informal relationships, both within and outside political institutions, shape public policy and that groups are the sources of policy ideas. In other words, interest groups set the agenda, formulate policy and try to influence the executive to adopt such policies. It is assumed that various competing coalitions use different strategies to influence policy makers. Sabatier (1988) argued that conflicting strategies from different coalitions are mediated by policy brokers, whose main concern is identifying reasonable compromise to reduce intense conflict i.e., they are 'more concerned with system stability than with achieving policy goals' (Sabatier, 1991: 153). The resulting policy may therefore reflect the goals of the group that is able to use the best strategies to influence policy brokers.

According to the advocacy coalition framework, policy formulation and policy change in particular, is instigated by: (1) The interaction of competing advocacy coalitions within a policy subsystem; (2) changes external to the system (e.g., changes in socio-economic conditions, impact of policy decisions from other systems); and (3) the effects of relatively stable system parameters (e.g., constitutional rules, socio-cultural values and social structure). Members in the coalition are said to act together because of their shared belief systems to manipulate the rules of various governmental institutions to achieve their shared beliefs (Sabatier, 1988; 1991; Sabatier and Jenkins-Smith, 1993; 1999). The framework is credited for synthesising different approaches into a coherent and robust theory and for 
providing a way of 'mapping' the fluid and interactive phases of the policy process (Parsons, 1995).

However it is not without criticisms. Schlager (1995) and Schlager and Blomquist (1996) have criticised the advocacy coalition framework for its implicit assumption that actors who share similar core beliefs will act in concert. They described this assumption as dangerous, arguing that a shared policy belief is not sufficient to guarantee a concerted action. According to Schlager (1995) institutional heterogeneity may even create coordination problems:

The institutional differences among a legislator, a journalist, a director of a material interest group and an academic may very well limit their ability and their willingness, to cooperate with one another, even if they share similar beliefs (Schlager, 1995: 263).

In addition, Schlager and Blomquist (1996) argue that political actors engage in the policy process not primarily to respond to a perceived problem but also to advance their own political interests and careers. Similarly, Parsons (1995) questions whether beliefs (rather than greed, self-interest, or power) are actually the 'glue' that holds advocacy coalitions together. He argues that bureaucrats are not just neutral servants, but also have values and interests which they use to shape policy. In a later work Sabatier and JenkinsSmith (1999) acknowledged that by focusing on shared policy beliefs, the advocacy coalition framework neglected the interest of individuals and organisations. It is evident from the above discussions that no one approach to policy formulation is better than the other since each explains different things within the policy process. As amply asserted by Parsons (1995: xvii) 'no one theory or model can capture or explain the complexity involved in the web of decisions', therefore no single approach would be applied in discussing the findings of this study.

\section{Methodology}

The use of the concepts 'children' and 'young people' together in this study may seem confusing. Although the topic emphasizes on children and young people's participation the study only focused on those (aged 15-17) who are regarded as 'children' under the UN Convention on the Rights of the Child. However, the 15-17 year olds in this study regarded themselves as young people rather than children. Legally, 15-17 year olds are 'children' (defined as those less than 18 years) but in colloquial interactions 15-17 year olds are regarded as 'young people' hence the use of the two concepts together in this study. The study aimed to analyse the formulation and implementation of Ghana's youth policy and explore the efforts toward mainstreaming young people's participation in the process. The questions that guided the study are:

- Are there barriers to involving young people in the policy process?

- How can young people's participation in the policy process be enhanced?

Due to the exploratory and open-ended nature of the research questions, a qualitative case-study framework was preferred. As argued by Duncan et al. (2009) it is advisable to choose a qualitative research approach when one is unsure of what answers to expect and also when one wants to maintain an open realm of response. As noted earlier, young people's participation in policy processes has been given little attention, hence a qualitative methodology was an appropriate choice to explore this under-researched area. A purposive sampling strategy was used to identify participants in the study. According to Mason (1996: 93-94), purposive sampling involves 'selecting groups or categories to study on the basis of their relevance to your research questions'. The target population sampled were policy makers (civil servants), lobbyists/advocates and young people (between 15 and 17 years). The sample for the young people was based on the assumption that younger children cope less with participation than older children (Pinkney, 2011) and also younger children may not understand policy issues. It is however acknowledged that age is not an accurate determinant of capacity. Settling on the lower age limit of 15 years is in accordance with the definition of youth as contained in Ghana's Youth Policy, while the upper age limit of 17 years is in line with the Convention on the Rights of Children's conception that anyone 18 years and over is an adult. The study involved interviews with 7 male key informants (4 policy-makers, 3 lobbyists) and focus group discussions with 13 young people (4 females and 9 males). In total 20 purposively chosen people were involved in the research.

The key informants were selected from organisations involved in the youth policy domain. As the key informants were from different organisations, slightly different interview guide was used for them. For example, key informants from the policy's implementing agency (National Youth Authority) were asked about how young people were engaged in the formulation of the youth policy. Whereas key informants from the other organisations (Strategic Youth Network for Development; World Youth Alliance; Young Men Christian Association) were asked about how they were lobbying the implementing agency to involve young 
people in the implementation of the youth policy. The key informants were selected on the basis of their knowledge about the youth policy or their participation in the formulation of the youth policy. Those at the National Youth Authority were selected because they were actively involved in the formulation of the policy or were involved in setting up the projects from which the young people for this study were selected. The other key informants selected from SYND, WYA and YMCA were selected because they had written newspaper articles or granted media interviews criticising the formulation and implementation of the youth policy (See Ezekiel, 2011; Obeng-Yeboah, 2011). The 13 young people sampled were engaged in 2 participatory projects i.e., Youth Advocacy Assembly and Curious Minds. The young people were drawn from these projects because the National Youth Authority had identified the projects as platforms to promote youth participation in decision-making.

Data was thematically analysed by following constructivist grounded theory procedures: initial coding and focused coding (Charmaz, 2006). Recorded interviews were personally transcribed by the researcher to enable familiarisation with the data. This is in consonance with Darlington and Scott's (2002) advice to researchers to transcribe the interview themselves as it stimulates engagement with the phenomenon being researched. Transcripts of the interviews were then coded using Atlasti.6 computer software. Saldaña (2009) outlines 29 different but not mutually exclusive ways of coding and argues that determining a coding method is influenced by the paradigm or theoretical approach to the study. In consonance with the constructivist/interpretivist paradigm of this study and to honour young people's voice and ground data analysis in their perspective (as espoused by the sociology of childhood and children's participation rights), in vivo codes were predominantly used. In vivo codes use 'direct language of participants as codes rather than researcher generated words or phrases' (Saldaña, 2009:48) in order 'to preserve participants' meanings of their views and actions' (Charmaz, 2006: 55). In presenting the findings interviewees are identified with excerpts of their interview data. The individuals identified gave written permission for them to be identified with excerpts from their interviews.

\section{Findings and Discussion of the Study}

The study identified a number of barriers to involving young people in the formulation of the youth policy. These barriers have been grouped into three categories: Individual attributes; socio-cultural factors; and political factors.

\section{Individual Attributes}

These are factors inherent in young people that are perceived to limit their capacity to contribute to national development process. The individual attributes identified in the study were perceived immaturity and limited life experience.

\section{Perceived Immaturity}

The study found that young people were perceived to lack the maturity required to participate in public decision-making. They were thought of as mentally and emotionally immature and are therefore incapable of making logical arguments in policy debates. As commented by a key informant:

There is a belief that 15-17 year old young people are not matured yet, that this group of young people cannot take decisions for themselves, how much more contribute to government policy? (Mohammed Harmis, Country Director - World Youth Alliance, Ghana).

Mohammed's statement has a cultural underpinning that will be discussed later under socio-cultural factors. The young people also gave their opinion on why they are not involved in public decision-making:

I think they see the youth to have small brains, our thinking is not as the adults. But we should be allowed to say what we want to say even with our small brains (Bernard, member of Curious Minds).

I also think we are seen as children and as we say children only think about themselves. So they think our thinking is shallow, we can't think of things that will benefit others (Edwin, member of Curious Minds).

It is believed that young people talk non-sense and cannot think seriously. They fear that young people will be arrogant if given the chance to sit with the elders. The young person might think that he is one of them and may do things not expected of him. As the proverb says a matured child could dine with the elders, but I don't think our society considers teenagers as matured children (Sophia, member of Youth Advocacy Assembly).

The maturity or immaturity of children and young people is a subject of much controversy. It is argued that making rational and autonomous decisions is the mark of 
maturity (Hart, 1982) and this group of people are regarded as lacking that ability.

\section{Limited Life Experience}

Some key informants stated that young people are not involved in policy-making because young people lack the experience and knowledge base needed for evidencebased policy-making. In other words young people lack the practical knowledge and work experience that is needed as the evidence to inform policy debates, a point illustrated by the remarks below:

About 15-17 year age group do not have much life experience even though their theoretical knowledge base can be quite appreciable. They can go and read about certain things but their limited life experience will limit their ability to contribute to decision-making as they do not have any anecdotal evidence to guide their decisions (a Deputy National Coordinator of Ghana National Youth Authority).

Other key informants corroborated this statement. For example, Reginald Crabbe (Secretary of Young Men Christian Association, Accra) argued that:

We want to promote youth participation in decision-making but we are looking at areas where they have experience so that they can share their knowledge and experiences in order to enrich the decision made. We cannot say let's involve them in road construction policy for example. That would be nonsensical since the young people have no experience in road construction.

Evidence-based policy requires that policies must be informed by rational analysis and credible evidence. It is believed that policies based on such systematic analysis and evidence produce better outcomes. According to Davies (2004 cited in Shaxson, 2005) evidence-based policy making requires the integration of experience, judgement and expertise supported with evidence from research. 15-17 years old young people are perceived to lack the ability to contribute to any of the matrix of experience, judgement and expertise required for evidence-based public policy discourse.

\section{Socio-Cultural Factors}

The second barrier to young people's participation is categorised into socio-cultural factors. These are practices embedded in Ghana's social structure that limit the capacity of young people to contribute to public policy processes. Socio-cultural ideologies to a very large extent determine children's perception of themselves and that of adults. The socio-cultural factors identified in the study are respect for elders; lack of autonomy; and nonparticipation in family decision-making.

\section{Respect for Elders and Authority}

The study found that young people's participation in the formulation of the youth policy was limited due to their inability to challenge the limited scope of the consultation exercise offered them because they did not want to be seen as disrespectful. In focus group discussions a young person commented that:

Some of us were tagged as disrespectful and culturally immature simply because we tried to challenge officials about some of the things been discussed at the youth conference. I believe they deliberately avoided those of us tagged as controversial whenever we raised our hands to make a contribution. I think this contributed to the small number of young people seen towards the end of the 3 day conference because they did not see the point of being there if you are not given the chance to talk (Osei, member of Curious Minds).

Although some other factors could have contributed to the dwindling number of young people by the end of the conference, it is important to highlight that the young people believed respect for elders limited their ability to challenge officials. Adu-Gyamfi (2014: 8) has argued that Ghana is a 'gerontocratically structured society where adult-child relations are structured on the basis of age'. Children and young people do not sit in the company of elders during community events and where their presence is allowed, they are expected not to contribute to the discussions but to silently observe. This, according to a young person is driven by "fear that young people will be arrogant if given the chance to sit with the elders or and may disrespect them because the young person might think that he is of the same status as the elders' (Adu-Gyamfi, 2014: 8). Tacitly, therefore children and young people acquiesce to 'adultism' and thus cannot challenge or disagree with decisions made by adults which they are not in favour of. Consequently, children and young people's participation in the policy process becomes limited due to their inability to freely express their views amidst adult-officials during policy consultation exercises.

\section{Lack of Autonomy}

In dimensions of childhood i.e. the points at which a child could be considered different from an adult, Archard (1993) noted that one of such points is autonomy (being responsible for ones deeds). If a person 
does not have the capability, for whatever reasons, to take important decisions in their life then such a person has not attained autonomy. Children and young people are dependent on adults (mostly their parents) for all major decisions about their lives: To marry, choice of school or college, pocket money etc. For this reason they are seen as lacking the capability to take decisions for themselves. Some key informants argued that young people do not have the required experience primarily because they are not given the autonomy to take decisions for themselves. For example, Mohammed Harmis (Country Director, World Youth Alliance) commented that:

I do not think that many parents in Ghana will allow their 15-17 years old son or daughter to go and look for work even if the young person wants to work.

Hence as young people are culturally deemed to lack autonomy to take important decisions in their life, they are also perceived to lack the capacity to contribute to evidence based policy-making.

\section{Non-Participation in Family Decision-Making}

As argued by Ochaíta and Espinosa (1997) the family is the ideal place to practice participation in decisionmaking. However, the preceding discussions indicate that the lack of autonomy and respect for elders do not only inhibit children and young people's participation in policy-making but also in family decision-making. In most countries children and young people are routinely not consulted when decisions are made in the family and community levels, hence the phrase 'children are seen but not heard' (UNAIDS, 2004). In this study young people reported that policy-makers, who are also family and community members, often transfer their attitudes at home to the work place. Consequently, they (policymakers) design policies for children and young people as a group without considering it necessary to consult them. Other key informants made similar comments about the transfer of attitude:

Even in our family lifestyle a father does not consult his children before making decisions for them so once they get into office they transfer the home attitude into office by deciding what they think the youth need. They don't even ask whether the youth like it or not (Chibeze Ezekiel, Executive Coordinator SYND).

\section{Political Factors}

The final barrier to young people's participation in policy-making is categorised as political factors. These are factors inherent in the political organisation of the country that inhibit young people's participation in policy. In the case of Ghana the factors identified in this study are political upheavals and violence; and lack of understanding and influence in governance systems.

\section{Political Upheavals and Violence}

Ghana has endured a number of political upheavals since independence and returned to democratic governance in 1992. Although the country has had 6 successful elections, campaigning for these elections have not been without violence and death. There are several reported stories of violence and death during political campaigns orchestrated by political opponents (see Meissner, 2010). The violence and risk of death do not enable parents to encourage young people to participate in political activities, as illustrated by the quotes below:

The frequent political violence has resulted in a situation where families do not want their children to attend political rallies in order not to put themselves at risk (Metropolitan Coordinator at the National Youth Authority).

In selecting young people for the young advocacy assembly some parents did not agree to their children's participation because they do not want their children to be involved in dirty politics. I had to personally go and meet some parents to explain to them that the youth advocacy assembly was not about getting their children into politics (Metropolitan Coordinator at the National Youth Authority).

Also, young people who express interest in political activities are discouraged by their parents. In the study, a 15 year old girl reported that she loved watching 'talking point' (a political discussion programme on TV) and attending youth rallies but her father disliked it so banned her from engaging in those activities. Her father always retorted:

What do you know about politics or why are you interested in politics, when you don't even have a vote (Justine, member of Curious Minds).

The experience of this 15 year old girl's desire to develop interest in political issues and been opposed by her father confirms Gordon's (2008: 34) argument that "girl's perceive their parents to be significant barriers to their activism in the public sphere". According to Watts and Gesson (2006 cited in Gordon, 2008: 34) 'parents 
play a central role in encouraging their kids to become civic-minded and even politically active'. Reddy and Ratna (2002) also highlight that parents can play a facilitative or inhibitive role in children and young people's participation.

\section{Lack of Influence on Governance System}

The study found that children and young people were perceived to lack understanding and influence in governance systems and therefore cannot contribute meaningfully to public decision-making. According to the regional secretary of YMCA:

Young people are not so informed of the issues at the table and they don't know the right tactics to engage duty bearers in order to meaningfully influence decisions (Reginald Crabbe)

The young people however stated that their perceived lack of understanding of governance system is directly related to their non-participation in the exercise of democratic franchise. As commented by a young person:

In national policies the government is looking at pleasing voters to ensure a renewal of its mandate to rule the country. Since 15-17 years old people do not vote the government does not see the need to please us because we have no direct influence in whether a government stays or goes out of power (Clara, member of Youth Advocacy Assembly).

Thoughts that children and young people are apolitical are well established (STC, 2012; Wyness, 2001). Therefore to involve young people in political activities and governance systems require creating new spaces for young people and allowing them to vote. The young person's above statement generated a lot of discussions on whether the voting age should be reduced. The study's original interview guide and focus group protocol had no question on voting but from the discussions at the focus group, other interviewees were asked whether the voting age should be reduced to include 15-17 year old youth. See section 4.3 for discussions on the voting age.

\section{Overcoming the Barriers to Young People's Participation}

This section outlines how the research participants thought the barriers to young people's participation in policy-making could be overcome. Some of the measures reported by the young people and key informants are respect and trust; responsibility and support; and political empowerment (i.e., the right to vote).

\section{Respect and Trust}

It was argued under the barriers to participation that unidirectional flow of respect from children and young people to elders and authority and their perceived immaturity was a hindrance to young people's participation. Unsurprisingly the young people reported that to enhance their participation policy-makers must show respect for their personhood and consider their views as worthy of solicitation whether what they have to say would be meaningful or not. In other words they reject the argument that they are immature and have limited life experience hence they would not have anything meaningful to contribute to policy making. They argued that policy makers must appreciate their unique knowledge base, their strengths and complement their shortfalls by dialoguing with them, explaining decisions and actions in a respectful way. According to the young people:

The idea that children should be seen and not heard should be discarded. They should trust our knowledge and give us a chance (Emmanuel, member of Curious Minds).

Well for me I think it is a matter of respect. They have to respect our very being and our human rights. They must listen to us even if we talk non-sense (Sophia, member of youth advocacy assembly).

\section{Responsibility and Support}

The study found that when young people are given appropriate responsibility and witness their influence on community action they are encouraged to participate. The young people reported that giving them the opportunity to assume responsibility for undertaking certain tasks increases their participation in projects. For example, leaders of the youth advocacy assembly reported that their participation increased dramatically to the point where they did not want to miss a meeting after they were given responsibility for collecting evidence of child prostitution and the involvement of children in drug trafficking. They also reported been involved in the discussion of what was to be done with the evidence collected, which resulted in a decision to demolish a dilapidated building that was been used as a brothel for child prostitution at night. According to a young person:

In most situations if they give us leadership positions we can demonstrate our competence as we did in the child prostitution case. We can do more in other cases if our elders give us the chance and support us (Sophia, member of youth advocacy assembly). 
As noted in the above quote, related to been given responsibility, is the issue of support to discharge that responsibility. Young people need support if they are to successfully participate in what is predominantly an adult dominated sphere. Policy formulation is a process that takes time and as identified in the barriers to participation in policy formulation most young people have limited knowledge of the process. Therefore young people require support to learn about the process and to join in. The young people in this study identified financial resources, training and culturally appropriate communication skills as some of the support they require. As argued by Baaba (member of youth advocacy assembly) "our politicians should train us and involve us in their activities so that we can learn from them". Other key informants reiterated that without support young people cannot really change what is essentially an adult establishment. In this regard, Reginald Crabbe (Secretary of Young Men Christian Association) argued that:

It is important that we as adults support to build the voice of young people, a voice that would be listened to. We need to train young people who are able to identify issues, frame them appropriately and adopt the right tactics and approaches in engaging duty bearers.

\section{Political Empowerment}

The young people in this study identified that their surest way to participate in public policy formulation is to be given the right to vote and be voted for in either local or national elections. They contend that their enfranchisement would compel politicians and policy makers to engage with them as they would have an influence in the governance systems in the country. It was argued in section 5.3.2 that young people's lack of influence in governance system was a contributory factor to their non-participation in policy-making. It is generally acknowledged that politics plays a crucial role in the formulation of public policies (Hill, 2009; Birkland, 2005), conversely policies also produce politics (Pierson, 1993). Tacitly therefore one cannot effectively be involved in policy formulation without involvement in some politics of a sort. The young people in this study unanimously argued that the voting age should be reduced to 15 years to enable them influence governance systems.

The young people strongly believed that they would be more involved or engaged in national or local policies if they had the power to determine who ruled at the national and local levels. In other words, if young people had the right to vote they would become a constituency that a government must please and canvass to seek their mandate. All the young people involved in this study argued for a reduction in the voting age to 15 years.
There was however disagreement among the adultparticipants in the study; some key informants agreed with the views of the young people about voting, whilst others disagreed. In supporting the call to lower the voting age, the Deputy National Coordinator argued that:

It is logical because if you want to involve 1517 year old people in decision-making at the national level, exercising their franchise will give them greater impetus.

The key informants who disagreed with the call to lower the voting age argued that 15-17 years old young people do not understand the rudiments of politics and the issues raised. They called for a period of civic education for young people since they do not yet understand the issues on offer, believing that civic education can help 15-17 year olds to make informed choices when they turn 18. For example, Chibeze Ezekiel (Executive Coordinator, Strategic Youth Network for Development) argued that

The assumption of voting is that matured people make well-informed decisions and since people mature at 18 years voting should remain at 18 years when they can understand the policies and proposals of candidates.

\section{Mohammed Harmis counter-argued that:}

Well understanding the issues you do not have to be older. Even there are many older people who do not understand the issues yet they vote. In any case voters do not understand or agree with all the policies of candidates before voting for them. Some vote for a candidate because they like some of that candidate's policies and I think 15 years old people have the mental capacity to like or dislike some policies. At the age of 15 they enter secondary schools where they think about abstract concepts and make practical sense of these concepts. Therefore they are wise enough to be civically competent (Mohammed Harmis, Country Director - World Youth Alliance Ghana).

Also the argument about the immaturity of 15-17 year old young people highly undermines the spirit of youth participation. Seeking to promote youth participation in public policy and denying young people the opportunity to vote on the presumption that they are immature is superfluous. If voting to choose a candidate is a matured task that cannot be done by 15 17 year olds, then how could they contribute to 
debates and discussions about policy options, which require negotiation skills and intellectual acumen? It can be concluded that if 15-17 year old young people are not matured to vote then they are not matured to participate in deliberations about policy options. However such arguments are flawed bearing in mind that voting was once the exclusive preserve of men aged 21 and over. Could it have been argued that 1820 years old people were not matured to vote or that women at whatever age were not matured to vote? Just as it was argued by feminists and the women suffrage movement that the denial of voting rights to women was the result of patriarchal patronage, it can also be argued that the denial of voting rights to young people is as a result of 'gerontocratic' patronage. As argued by an adult informant:

Giving 15-17 old the right to vote and be voted for in elections will be chaotic. Just imagine a parliament full of teenagers or that teenagers become mayors and ministers, they will think they are now equal or superior to their elders and may disrespect them.

This resonates with the discussion on socio-cultural factors, discussed in section 5.2.1 that respect for elders and authority inhibits young people's participation. Whereas some of the adult informants use respect for elders and reverence to authority as a reason to deny young people the opportunity to fully contribute in the political sphere of society, all the young people involved in this study believed that empowering them to actively influence and shape the political sphere is the surest way to ensure their participation in policy making and implementation. However the Convention on the Rights of Children excluded children and young people from politics on the basis that 'the very status of a child means in principle the child has no political rights' (cited in Wyness, 2001:198). Nonetheless, with the African Youth Charter calling on African governments to respect the right of every young person to participate in all spheres of society, young people's demand for enfranchisement is not without merit.

\section{Discussion of Findings}

Ghana's effort at formulating the national youth policy was heavily influenced by the requirements of international governmental bodies. According to a senior management official of the National Youth Authority:

Ghana is a member of the UN system, AU and ECOWAS and being a member of these organisations obligates us to have youth policy to provide the framework for the development of young people. Ghana for that matter had no option but to make sure we obliged to these institutions. Attempts at developing the youth policy started in the late 1990s, when the government drafted a national youth policy in response to the 1995 UN world action plan for youth (Deputy National Coordinator).

Ghana's approach to the formulation of the youth policy reflected the incremental approach to policy formulation (Lindblom, 1959; 1979). Incrementalism posits that policy makers rely on the record of previous policies and make minor adjustments to future policies i.e., 'change by small steps' (Lindblom, 1979: 517). The youth policy was originally drafted in 1999 but the policy could not be launched for implementation as many criticisms were levelled against it for not actively involving young people and other youth organisations in the drafting of the policy. For example, one of the respondents in this study commented that among the criticisms levelled against the policy was that 'it had no action plan for its implementation' (Chibeze Ezekiel, Executive Coordinator of Strategic Youth Network for Development).

With a change in government on $7^{\text {th }}$ January 2001 (from the National Democratic Congress, NDC to the New Patriotic Party, NPP) the 1999 draft policy was abolished and the process of formulating a new youth policy that will engage more young people and youth organisations began. As emphasised by UNESCO (2004), the importance of engaging young people cannot be underestimated. In formulating the new youth policy the deputy national coordinator reiterated that the youth authority was guided by the provisions in the 1999 policy, a further demonstration of incrementalism in the formulation of the youth policy. According to him:

We looked at the criticisms that were made against the 1999 policy and we consulted with the youth to improve the policy so that all stakeholders will accept it.

In promoting young people's participation in policy processes, the study highlights an important need for adult allies. It was argued that parents worry about the safety of their children during political rallies and as a result were reluctant to allow their young people to participate in political activities. However the intervention of the metropolitan coordinator of the national youth authority allayed the fears of some parents and they allowed their children to participate in the youth advocacy assembly. This suggests that the presence of adult allies or mediators is important in seeking to promote young people's political activism. Also considering that young people have limited 
participation in public policy-making due to the perception that they are immatured and inexperienced the presence of adult allies could be very useful in supporting young people in the public sphere. Adult mediators were found to be particularly important in promoting girls participation in political activities in a study by Gordon (2008) in which 'adult allies buffered the impact of parental worry on girls by serving as a crucial interface to concerned parents' (p. 48). Also, the role of adults in promoting children and young people's participation was again highlighted in a study by Gunn (2002) who argued that to increase youth participation in policy making 'young people should be supported by appropriately trained adults ... to identify areas for change and formulate a strategy to pursue these' ( $p$. 219). As concluded by Lansdown (2010):

Children and young people's relatively powerless status mean that they can only sustain participation where there are adults to facilitate the process (Lansdown, 2010: 16).

The young people in this study showed a strong desire to be involved in conventional politics and thus called for the lowering of the voting age to 15 years. This suggests that the young people have interest in politics and want to engage in democratic governance. According to Mayo (2001: 285) 'even relatively young children can develop a genuine appreciation of democracy and a sense of their own competence and responsibility'. It is argued that children's participation is aimed at promoting children's citizenship and empowerment (Boyden, 1990; Ackermann et al., 2003). This should include considering them as political agents instead of the apolitical status normally ascribed to them (Wyness, 2001; STC, 2012) for political rights are fundamental to the concept of citizenship (Lintello, 2011; Tonge and Mycock, 2010). Therefore the denial of political rights to 15-17 year old young people implies their exclusion from processes that have significant impact on their lives and for which they should be involved as empowered citizens. Gunn (2002: 186) argues that 'citizenship implies group participation through the ballot box'. However, voting as a civic responsibility for young people has been overlooked. As argued by Tonge and Mycock (2010) the nonparticipation of young people in voting undermines democracy. This is supported by Lecce (2009: 134) who argues that 'democracy is inseparable from voting'.

A few countries have reduced their voting age to 16 years to enable more young people to participate in the governance of their country. In Austria, Brazil, Cuba, Nicaragua, Isle of Man and Jersey (British territories), Ecuador and Somalia voting starts at the age of 16 years. In Norway and Israel 16 year olds can vote in local elections. In Sudan, Indonesia, East Timor and North Korea 17 year olds vote in all elections. Malaysia and Singapore have their voting age set at 21 years, whereas voting begins at 15 years in Iran (White, 2013). Other countries e.g., UK has had a consultation exercise on whether to reduce the voting age to 16 years. In the UK consultation, $64 \%$ of 16 and 17 year olds were in favour of lowering the voting age, but all the adults (i.e., 18+) in the consultation opposed lowering the voting age (YCC, 2009). The different ages at which people are allowed to vote reflects the social construction of the concept of childhood. For while in Iranian and Somalian societies 15 and 16 year olds are matured to participate in democratic citizenship, even 20 year olds are not considered matured enough for such roles in Malaysian and Singaporean societies. Although in Indonesia the voting age is set at 17 years, anyone below 17 years who is married can vote (Ananta et al., 2005). This resonates with the argument in section 5.2.2 (dimension of childhood and autonomy) that getting married marked the end of childhood in some societies. Also the fact that 15 and 16 year olds are able to vote in some countries while 20 year olds do not vote in some countries reflect the cultural relativity of rights.

According to Wyness (2001) citizenship is a precondition for political participation. However, children are given recognition as citizens when they leave childhood. Nonetheless, the stage at which childhood ends is culturally determined, but politically and legally most countries have adopted the age of 18 years to mark the end of childhood. It has however been argued that the adoption of 18 years as the age of maturity and assumption of competence is fixed too late (Houlgate, 1979). Therefore, in the citizenship discourse and political participation, the argument of the young people in this study that young people have the capability to engage in the exercise of democratic franchise at an earlier age than 18 years is worth serious consideration. The argument of some key informants in this study that young people do not understand electioneering and therefore need a period of civic education is flawed. This is in view of a study by Amadeo et al. (2002) of 14-19 year old young people in which it was found that young people 'have a fairly strong grasp of most of the basic tenets of democracy, including those factors likely to strengthen and weaken it' (p. 77).

Also, Torney-Purta et al. (1999) found that civic education does not necessarily create political interest among students. Haste (2013) has further argued that knowledge alone is not enough to predict future activism. Young people need avenues to practice democracy in order to create political interest that may transcend to adulthood. As noted by Sloam (2012b) young people's initial experiences of democratic engagement are more likely to persist into their 
adulthood. Consequently, a democratic school climate is more likely to promote the engagement of young people as adults (Haste, 2013). Young people in Ghanaian schools participate in school-democracy whereby they elect their student leaders such as Senior Prefects, Dinning Hall Prefects, Entertainment Prefects, Student Representative Council Presidents etc. Candidates for these positions campaign to their fellow students to outline what they will do if voted for. It is the same democratic principle at the national level which these young people can understand and participate in. As argued by Flanagan (2003):

\begin{abstract}
The social incorporation of younger generations into the body politic and the development of habits that sustain the system are rooted in young people's experiences of membership in the institutions of their communities and the exercise of rights and fulfilment of responsibilities in those institutions (Flanagan, 2003: 257).
\end{abstract}

It is therefore important that young people's engagement in governance is actively sought so that they can vote for candidates whose manifestoes/programmes are children and young people focused. Amadeo et al. (2002) have argued that as young people prepare to become adults, politics becomes more salient to them as they strive 'to make decisions about beginning careers, establishing families, entering military service, finding their own housing or other life transitions' (p. 109).

\section{Conclusion}

This paper has outlined the barriers to $15-17$ year old young people's participation in public policy-making and how to overcome the barriers. From the perspectives of policy makers these young people are immature and inexperienced, hence have limited ideas to contribute to policy discourse. However, from the perspectives of these young people they are not participants in public policymaking because they do not have the right to participate in politics. Although both perspectives are plausible it is important to highlight that young people's rights to participate in decisions that affect them is premised on the basis of their maturity. Nonetheless, granting voting rights to 15-17 year olds would be consistent with article 21 (3) of the universal declaration of human rights and article 25 of the international covenant on civil and political rights. The said articles state that:

The will of the people shall be the basis of the authority of government; this will shall be expressed in periodic and genuine elections which shall be by universal and equal suffrage and shall be held by secret vote or by equivalent free voting procedures (Article 21 (3) of Universal Declaration of Human Rights, emphasis added).

This declaration applies to $15-17$ year olds as well, as Article 2 of the declaration also states that:

Everyone is entitled to all the rights and freedoms set forth in this declaration, without distinction of any kind (emphasis added).

The international covenant on civil and political further requires that:

Every citizen shall have the right and opportunity, without distinction of any kind...to vote and to be elected at genuine periodic elections which shall be by universal and equal suffrage (Article 25, emphasis added).

Since the policy process is a political enterprise (Dowding, 1996; Sutton, 1999; Mooij, 2003; Hallsworth et al., 2011) to effectively enable young people to participate in this enterprise they need to possess and exercise democratic franchise. As argued by Sloam (2012a: 5) 'if young people do not vote, politicians are less likely to take their interests seriously'. Lecce (2009: 136) concurs by arguing that 'since the young are so disproportionately powerless relative to the elderly, law and policy-makers have very little incentive to take young people's interests and preferences seriously'. Therefore, the call by the 15-17 year old young people for their enfranchisement has merit as they have interests to promote and protect.

\section{Acknowledgment}

I would like to thank a Metropolitan Coordinator and an Administrative Secretary of the National Youth Authority, who wish to be anonymous for their assistance in getting young people for this research and also for linking me to some reluctant individuals and organisations.

\section{Funding information}

I am grateful to Royal Holloway, University of London for awarding me a College Research Scholarship without which, I could not have embarked on this research.

\section{Ethics}

The article is based on research that received ethical approval from Royal Holloway, University of London Research Ethics Committee. 


\section{References}

Ackermann, L., F. Thomas, J. Hart and J. Newman, 2003. Understanding and evaluating children's participation: A review of contemporary literature. Plan International.

Adu-Gyamfi, J., 2014. Childhood construction and its implications for children's participation in Ghana. Afr. J. Soc. Sci., 4: 1-11.

Amadeo, J., J. Torney-Purta, R. Lehmann, V. Husfeldt and R. Nikolova, 2002. Civic Knowledge and Engagement: An IEA Study of Upper Secondary Students in Sixteen Countries. 1st Edn., IEA, Amsterdam, ISBN-10: 9080664332, pp: 213.

Ananta, A., E.N. Arifin and L. Suryadinata, 2005. Emerging Democracy in Indonesia. 1st Edn., Institute of Southeast Asian Studies, Singapore, ISBN-10: 9812303227, pp: 166.

Anderson, J.E., 1975. Public Policy Making. 1st Edn., Praeger Publishers, New York.

Archard, D., 1993. Children: Rights and Childhood. 1st Edn., Routledge, London, ISBN-10: 0415082528, pp: 188 .

Birkland, T.A., 2005. An Introduction to the Policy Process: Theories, Concepts and Models of Public Policy Making. 2nd Edn., M. E. Sharpe, New York, ISBN-10: 0765614898, pp: 297.

Boulding, K.E., 1964. The Meaning of the Twentieth Century: The Great Transition. 1st Edn., Harper and Row, New York, pp: 199.

Boyden, J., 1990. Childhood and the Policy Makers: A Comparative Perspective on the Globalization of Childhood. In: Constructing and Reconstructing Childhood: Contemporary Issues in the Sociological Study of Childhood, James, A. and A. Prout (Eds.), Falmer Press, pp: 190-230.

Carlsson, L. and A. Sandstrom, 2008. Network governance of the commons. Int. J. Commons, 2: 33-54.

Charmaz, K., 2006. Constructing Grounded Theory: A Practical Guide Through Qualitative Analysis. 1st Edn., Sage Publications, London, ISBN-10: 0761973532, pp: 208.

Checkoway, B., T. Allison and C. Montoya, 2005. Youth participation in public policy at the municipal level. Child. Youth Services Rev., 27: 1149-1162. DOI: 10.1016/j.childyouth.2005.01.001

Cox, S., C. Dyer, A. Robinson-Pant and M. Schweisfurth, 2010. Children as Decision Makers in Education. 1st Edn., Continuum International, London, ISBN-10: 1441185658, pp:192.

Darlington, Y. and D. Scott, 2002. Qualitative Research in Practice: Stories from the Field. 1st Edn., Open University Press, Buckingham, ISBN-10: 1865085227, pp: 208.
Dowding, K., 1996. Power. 1st Edn., Open University Press, Buckingham.

Dror, Y., 1964. Muddling Through-"Science" or Inertia? Public Admin. Rev., 24: 153-157. DOI: $10.2307 / 973640$

Duncan, R.E., S.E. Drew, J. Hodgson and S.M. Sawyer, 2009. Is my mum going to hear this? Methodological and ethical challenges in qualitative health research with young people. Soc. Sci. Med., 69: 1691-1699. DOI: $10.1016 /$ j.socscimed.2009.09.001

Eriksson, M. and E. Näsman, 2008. Participation in family law proceedings for children whose father is violent to their mother. Childhood, 15: 259-275. DOI: $10.1177 / 0907568207088426$

Etzioni, A., 1967. Mixed-scanning: A "third" approach to decision-making. Public Admin. Rev., 27: 385-392. DOI: 10.2307/973394

Etzioni, A., 1986. Mixed scanning revisited. Public Admin. Rev., 46: 8-14. DOI: 10.2307/975437

Ezekiel, S.C., 2011. The National Youth Council (NYC): A bane or blessing?

Fanelli, C.W., R. Musarandega and L. Chawanda, 2007. Child participation in Zimbabwe's national action plan for orphans and other vulnerable children: Progress, challenges and possibilities. Child. Youth Environ., 17: 122-145.

Fitzgerald, R.M., 2009. Children having a say: A study on children's participation in family law decision making. PhD Thesis, Southern Cross University, Lismore, NSW.

Flanagan, C., 2003. Developmental roots of political engagement.

Gerston, L.N., 1997. Public Policy Making: Process and Principles. 1st Edn., M.E. Sharpe, New York, ISBN-10: 0765627434, pp: 164.

Gordon, H.R., 2008. Gendered paths to teenage political participation: Parental power, civic mobility and youth activism. Gender Society, 22: 31-55. DOI: 10.1177/0891243207311046

Grindle, M. and J. Thomas, 1991. Public Choices and Policy Change: The Political Economy of Reform in Developing Countries. 1st Edn., John Hopkins University Press, Baltimore, ISBN-10: 0801841569, pp: 240.

Gunn, R., 2002. Young people's participation in social services policy making. $\mathrm{PhD}$ Thesis, University College Northampton.

Gunn, R., 2005. Young people's participation in social services policy making. Res. Policy Plann., 23: 127137.

Gunn, R., 2008. The power to shape decisions? An exploration of young people's power in participation. Health Soc. Care Community, 16: 253-261. DOI: 10.1111/j.1365-2524.2008.00779.x 
Gyimah-Boadi, E., 2004. Civil society and Democratic Development. In: Democratic Reform in Africa: The Quality of Progress, GyimahBoadi, E. (Ed.), Lynne Reinner, Boulder, CO., ISBN-10: 1588262464, pp: 99-119.

Haas, P., 1992. Epistemic Communities and International Policy Coordination. Int. Organisat., 46: $1-35$.

Hallsworth, M., S. Parker and J. Rutter, 2011. Policy making in the real world: Evidence and analysis. Institute for Government.

Harrold, P., 2000. Setting the Context of Civil Society Engagement. In: The Role of Civil Society in Assessing Public Sector Performance in Ghana, Mackey, K. and S. Gariba (Eds.), The World Bank, Washington, DC., pp: 3-4.

Hart, H.L.A., 1982. Essays on Bentham: Studies in Jurisprudence and Political Theory. 1st Edn., Clarenden Press, Oxford, ISBN-10: 0198254687, pp: 272.

Haste, H., 2013. Getting Voices to be Heard: What Engages Critical Commitment and Empowerment. Proceedings of the Workshop on Crisis and Transition: The Participation of Young People in British Democracy, (PRD' 13), Royal Holloway University, London.

Hill, M., 2009. The Public Policy Process. 5th Edn., Pearson Longman, London, ISBN-10: 1405873523, pp: 352.

Horelli, L., 1998. Creating child-friendly environments: case studies on children participation in 3 European countries. Childhood, 5: 225-239

Houlgate, L.D., 1979. Children, Paternalism and Rights to Liberty. In: Having Children: Philosophical and Legal Reflections on Parenthood, O'Neill, O. and W. Ruddick (Eds.), Oxford University Press, Oxford,

Howlett, M. and M. Ramesh, 2002. The policy effects of internationalization: A subsystem adjustment analysis of policy change. J. Comparative Policy Anal. Res. Pract., 4: 31-50.

DOI: $10.1080 / 13876980208412669$

John, P., 1998. Analysing Public Policy. 1st Edn., Continuum, London, ISBN-10: 0826454240, pp: 227.

John, P., 2001. Policy Networks. In: The Blackwell Companion to Political Sociology, Nash, K. and A. Scott (Eds.), Blackwell Publishers, Oxford.

Kassan, D.G., 2004. How can the voice of the child be adequately heard in family law proceedings? LLM Thesis, University of the Western Cape, South Africa.

Kirby, P. and S. Bryson, 2002. Measuring the magic: Evaluating and research young people's participation in decision-making. Carnegie Young People Initiative, London.
Kpessa, M.W., 2011. The politics of public policy in Ghana: From closed circuit bureaucrats to citizenry engagement. J. Develop. Societies, 27: 29-56. DOI: 10.1177/0169796X1002700103

Lansdown, G., 2010. The Realisation of Children's Participation Rights: Critical Reflections. In: A Handbook of Children and Young People's Participation: Perspectives from Theory and Practice, Percy-Smith, B. and N. Thomas, (Eds.), Routledge, London.

Lecce, S., 2009. Should democracy grow up? Children and voting rights. Intergenerat. Justice Rev., 9: 133-139.

Levi, P., 1988. The Drowned and the Saved. 1st Edn., Vintage International, New York, ISBN-10: 067972186X, pp: 203.

Lindblom, C.E., 1959. The science of "muddling through". Public Admin. Rev., 19: 79-88.

DOI: $10.2307 / 973677$

Lindblom, C.E., 1979. Still muddling, not yet through. Public Admin. Rev., 39: 517-526. DOI: $10.2307 / 976178$

Lintello, D., 2011. Youth and policy processes. Future Agricultures, working paper 025.

Marsh, D. and R.A.W. Rhodes, 1992. Policy Networks in British Government. 1st Edn., Clarendon Press, Oxford, ISBN-10: 0198278527, pp: 320.

Mason, J., 1996. Qualitative Researching. 1st Edn., Sage Publications, London.

Mayo, M., 2001. Children's and young people's participation in development in the South and in urban regeneration in the North. Progress Dev. Stud., 1: 279-293.

DOI: $10.1177 / 146499340100100401$

McFerson, H.M., 2009. Measuring African governance: By attributes or by results? J. Dev. Societies, 25: 253-274. DOI: 10.1177/0169796X0902500206

Meissner, K., 2010. Elections and Conflict in Ghana. 1st Edn., Friedrich-Ebert-Stiftung, Berlin.

Mooij, J., 2003. Smart governance? Politics in the policy process in Andhra Pradesh, India. Overseas Development Institute.

Obeng-Yeboah, H., 2011 African youth are voiceless and powerless.

Ochaíta, E. and M.Á. Espinosa, 1997. Children's participation in family and school life: A psychological and development approach. Int. J. Child. Rights, 5: 279-297.

DOI: $10.1163 / 15718189720493690$

Parsons, W.D., 1995. Public Policy: An introduction to the Theory and Practice of Policy Analysis. 1st Edn., Edward Elgar, Cheltenham, ISBN-10: 1852785543, pp: 675. 
Pierson, P., 1993. When effect becomes cause: Policy feedback and political change. World Polit., 45: 595-628. DOI: 10.2307/2950710

Pinkerton, J., 2004. Children's participation in the policy process: Some thoughts on policy evaluation based on the Irish national children's strategy. Child. Society, 18: 119-130. DOI: 10.1002/chi.820

Pinkney, S., 2011. Discourses of children's participation: Professionals, policies and practices. Soc. Policy Society, 10: 271-283. DOI: $10.1017 / \mathrm{S} 1474746411000017$

Reddy, N. and K. Ratna, 2002. Journey in children's participation. The Concerned for Working Children. India.

Rhodes, R.A.W and D. Marsh, 1992. New directions in the study of policy networks. Eur. J. Political Res., 21: 181-205. DOI: $10.1111 /$ j.1475-6765.1992.tb00294.x

Rhodes, R.A.W., 1997. Understanding Governance: Policy Networks, Governance, Reflexivity and Accountability. Buckingham, Open University Press.

Sabatier, P.A. and H. Jenkins-Smith, 1993. Policy Change and Learning: An Advocacy Coalition Approach. 1st Edn., Westview Press, Boulder, Colorado, ISBN-10: 0813316499, pp: 290.

Sabatier, P.A. and H. Jenkins-Smith, 1999. The Advocacy Coalition Framework: An Assessment. In: Theories of the Policy Process, Sabatier, P.A. (Ed.), Westview Press, Boulder, Colorado.

Sabatier, P.A., 1988. An advocacy coalition framework of policy change and the role of policy-oriented learning therein. Policy Sci., 21: 129-168. DOI: 10.1007/BF00136406

Sabatier, P.A., 1991. Toward better theories of the policy process. Political Sci. Polit., 24: 147-156. DOI: $10.2307 / 419923$

Saldaña, J., 2009. The Coding Manual for Qualitative Researchers. 1st Edn., Sage Publications, London, ISBN-10: 1847875491, pp: 240.

Schlager, E. and W. Blomquist, 1996. A comparison of three emerging theories of the policy process. Political Res. Q., 49: 651-672.

DOI: $10.1177 / 106591299604900311$

Schlager, E., 1995. Policy making and collective action: Defining coalitions within the advocacy coalition framework. Policy Sci., 28: 243-270.

DOI: $10.1007 / \mathrm{BF} 01000289$

Shaxson, L., 2005. Is your evidence robust enough? Questions for policy makers and practitioners. Evidence Policy: J. Res. Debate Pract., 1: 101-111. DOI: $10.1332 / 1744264052703177$
Shier, H., 2001. Pathways to participation: Openings, opportunities and obligations. Child. Society, 15: 107-117. DOI: $10.1002 /$ chi.617

Simon, H.A., 1957. Models of Man: Social and Rational; Mathematical Essays on Rational Human Behavior in Society Setting. Wiley, New York, pp: 287.

Sloam, J., 2012a. Youth, citizenship and politics. Parliamentary Affairs, 65: 4-12.

DOI: $10.1093 / \mathrm{pa} / \mathrm{gsr} 048$

Sloam, J., 2012b. 'Rejuvenating democracy?' Young people and the 'big society' project. Parliamentary Affairs, 65: 90-114. DOI: 10.1093/pa/gsr051

Smith, T.B., 1973. The policy implementation process. Policy Sci., 4: 197-209. DOI: 10.1007/BF01405732

Spicer, N. and R. Evans, 2005. Developing children and young people's participation in strategic processes: The experience of the Children's Fund Initiative. Soc. Policy Society, 5: 177-188. DOI: $10.1017 / \mathrm{S} 1474746405002861$

STC, 2012. Children in Politics. Save the Children.

Sutton, R., 1999. The Policy Process: An Overview. 1st Edn., ODI, London, ISBN-10: 0850034175, pp: 35.

Teye, J., 2008. Forest resource management in Ghana: An analysis of policy and institutions. PhD Thesis, University of Leeds.

Thomas, N. and C. O'Kane, 1999. Experiences of decision-making in middle childhood: The example of children 'looked after' by local authorities. Childhood, 6: 369-387. DOI: $10.1177 / 0907568299006003005$

Tonge, J. and A. Mycock, 2010. Citizenship and political engagement among young people: The workings and findings of the youth citizenship commission. Parliamentary Affairs, 63: 182-200. DOI: $10.1093 / \mathrm{pa} / \mathrm{gsp} 049$

Torney-Purta, J., J. Schwille and J. Amadeo, 1999. Civic Education Across Countries: Twenty-four National Case Studies from the IEA Civic Education Project. 1st Edn., IEA, Amsterdam, ISBN-10: 9051666713, pp: 624.

True, J.L., B.D. Jones and F.R. Baumgartner, 1999. Punctuated-Equilibrium Theory: Explaining Stability and Change in American Policymaking. In: Theories of the Policy Process, Sabatier, P.A. (Ed.), Westview Press, Boulder, Colorado, pp: 97-115.

UNAIDS, 2004. Seen but not heard; very young adolescents aged 10-14 years. UNAIDS.

UNESCO, 2004. Empowering Youth through National Policies. UNESCO.

Veitch, H., 2009. Participation in practice: An evaluation of the primary school council as a participatory tool. Childhoods Today. 
Vis, S.A., A. Strandbu, A. Holtan and N. Thomas, 2010. Participation and Health-a research review of child participation in planning and decisionmaking. Child Family Soc. Work, 16: 325-335. DOI: $10.1111 / \mathrm{j} .1365-2206.2010 .00743 . x$

White, I., 2013. Voting Age.

Williams, E., 2004. Children's participation and policy change in Asia. CHIP report No. 6.

Williams, E., 2005. Small hands, big voices? Children's participation in policy change in India. IDS Bull., 36: 82-90.

DOI: $10.1111 /$ j.1759-5436.2005.tb00182.x
Wilson, J.Q., 1980. The Politics of Regulation. 1st Edn., Basic Books, New York, ISBN-10: 0465059686, pp: 468.

Wyness, M.G., 2001. Children, childhood and political participation: Case studies of young people's councils. Int. J. Child. Rights, 9: 193-212. DOI: $10.1163 / 15718180120494937$

YCC, 2009. Old enough to make a mark? Should the voting age be lowered to 16 ? Youth Citizenship Commission. 